\title{
Extensive Rangewide Mitochondrial Introgression Indicates Substantial Cryptic Hybridization in the Golden-winged Warbler (Vermivora chrysoptera)
}

\section{L'introgression mitochondriale largement répandue dans l'ensemble de l'aire de reproduction indique l'existence d'une importante hybridation cryptique chez la Paruline à ailes dorées (Vermivora chrysoptera)}

\author{
$\underline{\text { Rachel Vallender }}^{1}, \underline{\text { Steven L. Van Wilgenburg }}^{2}$, Lesley P. Bulluck $^{3}$, Amber Roth $^{4}$, Ron Canterbury $^{5}$, \\ $\underline{\text { Jeffrey Larkin }}^{6}, \underline{\text { R. Monica Fowlds }}^{7}$, and Irby J. Lovette ${ }^{1}$
}

\begin{abstract}
Widespread population declines of the Golden-winged Warbler (Vermivora chrysoptera) are thought to be due in part to hybridization with the expanding Blue-winged Warbler (V. pinus), which predictably replaces Golden-winged Warblers at breeding sites in which the two species come into contact. However, the mechanism by which this replacement occurs remains unresolved. Recent genetic work has indicated that, even in areas where the two species have been in contact for a short period, introgression of Blue-winged mitochondrial (mtDNA) and nuclear genes into Golden-winged individuals is common. To explore this process on a broader scale, we screened more than 750 individuals from nine U.S. states and three provinces to examine geographic patterns of mtDNA introgression. The only population in which all phenotypic Golden-winged Warblers had Golden-winged mtDNA haplotypes, and in which there are no breeding Blue-winged or hybrid individuals, was in the province of Manitoba, near the northwestern edge of the species' breeding distribution. The near ubiquity of mitochondrial introgression suggests that there are far fewer genetically pure populations of Goldenwinged Warblers than previously believed, a finding with important implications for this threatened species.
\end{abstract}

RÉSUMÉ. On pense que le déclin à grande échelle des populations de Paruline à ailes dorées (Vermivora chrysoptera) est en partie attribuable à son hybridation avec la Paruline à ailes bleues ( $V$. pinus), laquelle est en expansion et remplace, comme on peut s'y attendre, la Paruline à ailes dorées aux sites de nidification où les deux espèces entrent en contact. Toutefois, le processus par lequel survient ce remplacement demeure inconnu. Des études génétiques récentes ont montré que, même aux endroits où les deux espèces n'ont été en contact que sur une courte période, l'introgression des gènes mitochondriaux (ADNmt) et nucléaires de la Paruline à ailes bleues chez les individus de Paruline à ailes dorées est commune. Pour explorer ce processus à plus grande échelle, nous avons procédé au criblage de plus de 750 individus provenant de neufs États des États-Unis et de trois provinces afin d'examiner les variations géographiques de l'introgression mitochondriale. La seule population dans laquelle toutes les Parulines à ailes dorées phénotypiques présentaient des haplotypes d'ADNmt de Paruline à ailes dorées, et dans laquelle il n'y avait pas d'individus nicheurs de Paruline à ailes bleues ni d'hybrides, se trouvait au Manitoba, près de la limite nord-ouest de l'aire de reproduction de l'espèce. La quasiomniprésence de l'introgression mitochondriale permet de croire qu'il y a beaucoup moins de populations génétiquement pures de Paruline à ailes dorées que ce qu'on pensait, une découverte significative pour cette espèce menacée.

Key Words: Blue-winged Warbler; conservation; genetic introgression; Golden-winged Warbler; hybridization; Vermivora chrysoptera; Vermivora pinus.

\footnotetext{
${ }^{1}$ Fuller Evolutionary Biology Program, Cornell Laboratory of Ornithology, ${ }^{2}$ Environment Canada, ${ }^{3}$ Department of Biology, Virginia Commonwealth University, ${ }^{4}$ School of Forest Resources and Environmental Science, Michigan Technological University, ${ }^{5}$ Department of Biological Sciences, University of Cincinnati, ${ }^{6}$ Department of Biology, Indiana University of Pennsylvania, ${ }^{7}$ University of Wisconsin
}

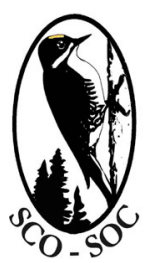

Sponsored by the Society of Canadian Ornithologists and Bird Studies Canada Parrainée par la Société des omithologistes du Canada et Études d'oiseaux Canada

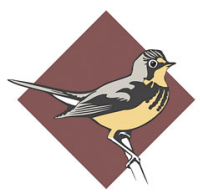

BIRD STUDIES CANADA 


\section{INTRODUCTION}

An increase in hybridization is thought to be occurring worldwide because of the destruction of isolating barriers and the introduction of invasive species (Allendorf et al. 2001, Gill 1980, Rhymer and Simberloff 1996). Hybridization is pertinent in a conservation context when it involves threatened or endangered species. Not only does hybridization cause practical problems for conservation efforts, e. g., hybrids are not afforded protection under some conservation regulations (Allendorf et al. 2001, Schwartz et al. 2004, Buehler et al. 2006), but it can also compromise the genetic integrity of a species to the point of its extinction. This outcome is poignantly illustrated by the American Black Duck (Anas rubripes), which has become so hybridized with the Mallard (A. platyrhynchos) that recent genetic analyses of Black Ducks suggest that a genetically pure Black Duck may no longer exist in North America (Mank et al. 2004).

Mosaic hybrid zones are areas of interaction between two species. These zones have a complex structure, often vary according to habitats and resources (Harrison 1993), and cover a large geographic expanse, so it is not surprising that few studies have assessed levels of introgression throughout the entire mosaic breeding range of two hybridizing taxa. Most studies are limited to areas of intensive study and sampling (Sattler and Braun 2000, Rohwer et al. 2001, Bronson et al. 2003). Furthermore, mosaic hybrid zones are inherently dynamic, so that results from one area may not be comparable to results from another (Gill 2004). To fully address the implications of hybridization for the species involved, it is necessary to document spatial variations in patterns of introgression. Documenting spatial patterns of introgression makes it possible to examine how variables such as habitat structure, species composition, and time since contact influence the pace and extent of introgressive hybridization.

The Golden-winged Warbler (Vermivora chrysoptera) has garnered intensive conservation attention (Buehler et al. 2006, 2007, COSEWIC 2006), because it has been undergoing significant rangewide population declines for more than $30 \mathrm{yr}$ $(-2.9 \% / y r, N=280$ routes, $p<0.0003$; Sauer et al. 2008). Some regional declines have been as high as 20-30\%/yr (from 1995 to 2004, -30.90\%/yr in Pennsylvania, $p<0.003 ;-28.52 \% / y r$ in West Virginia, $p<0.01$; Sauer et al. 2008), and this species is no longer present in many areas that it formally occupied. Since 1966, an estimated 64\% of the global population of this species has been lost, causing it to be identified as in need of immediate conservation attention by Partners in Flight (Rich et al. 2004), a species of global conservation concern and extremely high conservation priority by the Audubon Society (Butcher et al. 2007), and one of the fastest-declining passerine species in North America. Although not yet federally listed in the United States, the Golden-winged Warbler is listed as endangered in three states, namely Indiana, Ohio, and Massachusetts; as rare or threatened in four states, specifically North Carolina, Maryland, Vermont, and Kentucky; and of special concern in five states: Wisconsin, Georgia, Connecticut, New Jersey, and New York (Buehler et al. 2006). In Canada, the species was listed as federally threatened in 2006 by the Committee on the Status of Endangered Wildlife in Canada (COSEWIC 2006).

Golden-winged Warbler declines are attributed primarily to a combination of habitat loss (e.g., Buehler et al. 2006, 2007, Hunter et al. 2001) and hybridization with the closely related Blue-winged Warbler ( $V$. pinus). These species, although traditionally allopatric, were put into contact via human manipulation of the landscape in the 1800s (Gill 1980), and hybridization appears to have been taking place ever since. Although we do not yet fully understand how hybridization directly affects Golden-winged Warbler demographics, hybridization between Golden-winged and Blue-winged Warblers is commonplace in all areas in which the two species are in contact and typically leads to the local extirpation of Golden-winged Warblers (Gill 1980). To elucidate the impact of hybridization on Goldenwinged Warblers, recent studies have used genetic techniques to examine patterns and levels of introgression between these species. Most such investigations have used maternally inherited mitochondrial DNA (mtDNA) markers (Gill 1987, 1997, Shapiro et al. 2004, Dabrowski et al. 2005, Vallender et al. 2007a) to examine the rate and direction of gene flow between these species in various regions throughout their breeding ranges. Whereas Gill's (1997) work suggested unidirectional mtDNA gene flow from Blue-winged to Goldenwinged Warblers, later work determined that hybridization is more often bidirectional (Shapiro et al. 2004, Dabrowski et al. 2005, Vallender et al. $2007 a$ ) and that mismatches between phenotype and mtDNA haplotype regularly occur, e.g., up to $33 \%$ 
of birds in a population in New York (Dabrowski et al. 2005), in areas in which the species co-exist.

Whereas the use of mtDNA markers has greatly improved our understanding of hybridization between Golden-winged and Blue-winged Warblers, it provides only a partial window into patterns of hybridization because it is maternally inherited and clonal. Thus, mtDNA only provides information about female-mediated gene flow. The inclusion of data from nuclear DNA, which is biparentally inherited, would add a greater depth of understanding to an examination of introgression and make it possible to identify cryptic hybrids even when there is no mismatch between phenotype and mtDNA haplotype (Vallender et al. 2007a). However, widespread mtDNA screening provides a rapid, rangewide overview of hybridization and is an excellent first-pass index of past introgression. A genetic census is an informative first step in the conservation of the Golden-winged Warbler. Thus, the primary objective of our study was to provide the first rangewide assessment of mtDNA introgression between Golden-winged and Bluewinged Warblers.

\section{METHODS}

We screened a total of 753 samples $(N=608$ Golden-winged Warblers, $N=145$ Blue-winged Warblers) originating from nine states and three provinces (Table 1). The 35 samples from Kentucky and 19 of the samples from Manitoba were used in a previous study (Vallender et al. 2007a) during which their entire NDII gene was sequenced and they were assigned to ancestral Golden-winged or Blue-winged haplotype groups via phylogenetic analyses (see Dabrowski et al. 2005). All 54 of these individuals were assigned to the haplotype group that coincided with their phenotype and were also assigned to their predicted ancestral group by a panel of amplified fragment-length polymorphisms (Vallender et al. 2007a). Therefore, these samples acted as our controls during this study.

Only individuals that conformed to the classic Golden-winged and Blue-winged Warbler phenotypes (Parkes 1951) were included in our analyses. The inclusion of samples from both species allowed us to look for evidence of bidirectional gene flow (Shapiro et al. 2004, Dabrowski et al. 2005). Any individual with a phenotype-haplotype mismatch was thereby considered a cryptic hybrid (Vallender et al. 2007a). We did not include any phenotypic hybrids, e.g., "Brewster's" or "Lawrence's" Warblers (Parkes 1951), or otherwise phenotypically introgressed individuals (Vallender et al. 2007a) in our sample, because by definition they have mixed ancestry.

Previous studies (Gill 1987, 1997, Shapiro et al. 2004, Dabrowski et al. 2005) of mtDNA variation in Golden-winged and Blue-winged Warblers have documented a $3.0 \%$ (cytochrome- $b$ ) to $4.5 \%$ (NDII) mitochondrial sequence divergence between the ancestral mitochondrial genomes of these species, with much lower levels of within-species haplotypic variation. The substantial existing evidence suggests that the two species were reciprocally fixed for their respective mitochondrial lineages, with subsequent mixing caused by introgressive hybridization. Under this assumption, our tests for a mismatching phenotype and mitochondrial genotype will detect any past female-line hybridization events in the ancestry of a particular individual. As such, we were confident that we would be able to find species-diagnostic single nucleotide polymorphisms (SNPs) for use in classifying individuals to one group or the other.

To assign individuals to their ancestral haplotype group we used a combination of polymerase chain reaction (PCR) and fragment digest using a restriction endonuclease. We compared existing NDII sequences from both Blue-winged and Golden-winged Warblers using SEQUENCHER 4.7 (Gene Codes Corporation, Detroit, Michigan, USA) and generated a consensus sequence for each species. After aligning the consensus sequences of the two species, we then searched them for SNPs that showed fixed differences. A total of 25 SNPs were found in a 619 base pair (bp) section of NDII. We based our subsequent RFLP assay on two SNPs at positions 277 and 279 relative to the Zebra Finch NDII gene (Stapley et al. 2008; GenBank reference \#DQ422742). The Blue-winged Warbler variant at this site (ACGT) is cleaved by restriction enzyme MaeII (HpyCHIV; New England Biolaboratories, Ipswich, Massachusetts, USA), whereas the Golden-winged Warbler variant (GCAT) is not cut. To facilitate processing, we designed primers $\mathrm{F} 2$ (5' - AGC CAT TGA AGC CGC TAC CAA GTA - 3') and R1 (5' - GGA GTT TTA TGA TGG TTG ATA GGA GGA G - 3') flanking the cut site, and that generated a 282-bp fragment via PCR. 
Table 1. Number of Golden-winged (GWWA) and Blue-winged

Warbler (BWWA) samples collected in each state/province.

\begin{tabular}{lcc}
\hline \hline State/Province & GWWA & BWWA \\
\hline Minnesota & 96 & 5 \\
Wisconsin & 123 & 12 \\
Missouri & 0 & 20 \\
Kentucky & 0 & 35 \\
Tennessee & 93 & 0 \\
North Carolina & 18 & 0 \\
West Virginia & 24 & 38 \\
Pennsylvania & 38 & 3 \\
New York & 89 & 23 \\
Manitoba & 95 & 0 \\
Ontario & 27 & 8 \\
Quebec & 5 & 1 \\
\hline
\end{tabular}

All amplifications contained $1.0 \mu \mathrm{L} 1 \mathrm{X}$ reaction buffer (Sigma-Aldrich, St. Louis, Missouri, USA), $0.2 \mu \mathrm{M}$ each forward and reverse primers, $0.02 \mathrm{mM}$ deoxyribonucleotide thriphosphate (dNTP; each), $2.5 \mathrm{mM} \mathrm{MgCl}_{2}$ (Sigma), 0.2 U JumpStart Taq polymerase (Sigma), 100-250 ng genomic DNA, and DNA-grade water (Fisher Scientific, Hampton, New Hampshire, USA) to a final volume of $10 \mu \mathrm{L}$. Cycling profiles included one cycle at $95^{\circ} \mathrm{C}$ for 3 min, followed by 34 cycles at $95^{\circ} \mathrm{C}$ for $1 \mathrm{~min}, 1 \mathrm{~min}$ at $53^{\circ} \mathrm{C}$, and $1 \mathrm{~min}$ at $72^{\circ} \mathrm{C}$. The program ended with one cycle at $72^{\circ} \mathrm{C}$ for $5 \mathrm{~min}$, followed by a continuous hold at $10^{\circ} \mathrm{C}$.

Once PCR product was confirmed, we diluted $5 \mu$ L of PCR product in $9 \mu \mathrm{L}$ DNA-grade water (Fisher Scientific) and added $2 \mu \mathrm{L}$ MaeII (New England BioLaboratories) and $4 \mu \mathrm{L}$ NEB buffer 1 (New England Biolaboratories) for a total volume of $20 \mu$ L. The samples were then held at $37^{\circ} \mathrm{C}$ for $3 \mathrm{hr}$, followed by $65^{\circ} \mathrm{C}$ for $20 \mathrm{~min}$ to deactivate the restriction enzyme.
Fragments were scored by running them on a standard 2\% agarose gel (Fisher Scientific Molecular Biology Grade Agarose, 1X TAE buffer, $0.25 \mathrm{mg} / \mathrm{mL}$ EtBr). Samples that showed two bands of almost the same size ( 140 bp) were assigned to the Blue-winged Warbler group, whereas samples showing only one band ( $280 \mathrm{bp}$ ) were assigned to the Golden-winged Warbler group. A 1+ KB DNA ladder size standard (Invitrogen, Carlsbad, California, USA) was run alongside the samples to allow classification by size. Two known Goldenwinged and two known Blue-winged Warbler DNAs were included as controls in each set of reactions, as was a 5- $\mu \mathrm{L}$ sample of genomic DNA. These positive controls assured that the restriction enzyme was working effectively.

To verify that our method was reliable, we examined NDII sequences $(\sim 690 \mathrm{bp})$ that we had generated previously (Dabrowski et al. 2005, Vallender et al. 2007a) from an additional 111 Golden-winged Warblers and 20 Blue-winged Warblers. All but one of the Golden-winged Warblers was assigned to the 
same haplotype group using either method, i.e., phylogenetic analysis or PCR-RFLP assay. One Golden-winged Warbler would have been assigned to the Golden-winged Warbler haplotype group using the PCR-RFLP method because of a point mutation at the cut site, whereas analysis of the complete NDII gene using phylogenetic analyses (Dabrowski et al. 2005) assigned it to the Bluewinged Warbler haplotype group. All 20 of the Blue-winged Warblers were assigned to the same haplotype group using either phylogenetic analyses or a PCR-RFLP assay. A single case of misassignment (1/131) using the PCR-RFLP method indicates that our technique is robust and that analysis of the entire NDII gene is not necessary for classification to Golden-winged or Blue-winged Warbler haplotype groups.

\section{RESULTS}

\section{Golden-winged Warbler introgression}

In total, 49 of the 608 Golden-winged Warblers $(8.0 \%)$ showed mtDNA introgression (Table 2, Fig. 1 ), as evidenced by a mismatch between the phenotype of the bird and the mitochondrial haplotype classification. All states/provinces except Manitoba and Quebec showed some level of genetic introgression (Table 2, Fig. 1). The very small southern Ontario sample near Long Point showed no introgression $(N=2)$, but introgression was found in the more northern population near Kingston. The percentage of phenotype-mitochondrial haplotype mismatch varied by state/province, with the greatest levels of introgession occurring in New York (17\% mismatch), followed by mid-Wisconsin and Tennessee (both with a 14\% mismatch).

\section{Blue-winged Warbler introgression}

Of the 145 Blue-winged Warbler samples, 14 had a mismatch between their phenotype and mitochondrial haplotype (9.6\%). The Blue-winged Warbler samples obtained in Kentucky showed no sign of introgression (as was also shown in Vallender et al. 2007a; Table 2, Fig. 2). Similarly, all of the few samples collected in the more northern location in Ontario and in Quebec were found to have Bluewinged Warbler mtDNA. The samples from the southern Ontario site showed the highest level of introgression (43\%). Samples obtained in Missouri,
New York, and West Virginia showed very low levels of introgression despite moderate sample sizes.

\section{Interspecies comparison of introgression}

Similar to other recent studies (Shapiro et al. 2004, Dabrowski et al. 2005, Vallender et al. 2007a), our data suggest that mitochondrial introgression between Blue-winged and Golden-winged Warblers is bidirectional. Moreover, based on a chi-squared test of independence, there was no difference in the rate of introgression between species $\left(\chi^{2}=0.38\right.$, df $=1, p=0.54$ ).

\section{DISCUSSION}

If populations of Golden-winged Warblers that remain free from genetic introgression with Bluewinged Warblers are to be protected, we must first identify the scale and specific locations at which the genetically pure breeding populations exist. This study is the first rangewide analysis of genetic introgression within this system and hence represents a first step toward identifying where genetically pure populations of Golden-winged Warblers remain. Additional work to increase sample sizes, the addition of samples from more states, e.g., Michigan and Virginia, and the inclusion of data from nuclear markers are currently under way and will ultimately enhance our understanding of introgression and gene flow within this system. Findings from genetic surveys, such as the one carried out here, are time sensitive. Ongoing range expansion of Blue-winged Warblers into areas that were historically dominated by Golden-winged Warblers will likely put currently pure populations of Golden-winged Warblers into contact with Bluewinged Warblers in coming years (Gill 2004).

This survey suggests that Golden-winged Warbler populations in Manitoba remain free from introgression, because the 95 birds sampled were all assigned to the ancestral Golden-winged Warbler haplotype group. This same result was found in a previous study with a subset $(N=19)$ of these same samples collected in 1998 (Vallender et al. 2007a). The introgression-free status of the birds in this province has apparently not changed over the 10-yr period spanning these sample collections. Their genetic purity is further supported by the lack of 
Table 2. Phenotype by mitochondrial DNA haplotype associations listed by state/ province. Numbers indicate individuals. $\mathrm{ABW}=$ ancestral Blue-winged Warbler mitochondrial haplotype group, $\mathrm{AGW}=$ ancestral Golden-winged Warbler mitochondrial haplotype group.

\begin{tabular}{lcccc}
\hline \hline State/Province & \multicolumn{2}{c}{ Blue-winged Warbler } & \multicolumn{2}{c}{ Golden-winged Warbler } \\
& ABW & AGW & ABW & AGW \\
\hline New York & 20 & 3 & 15 & 74 \\
Ontario & 4 & 4 & 1 & 26 \\
Pennsylvania & 2 & 1 & 4 & 34 \\
Quebec & 1 & 0 & 0 & 5 \\
West Virginia & 36 & 2 & 1 & 23 \\
Minnesota & 5 & 0 & 1 & 95 \\
North Carolina & 0 & 0 & 2 & 16 \\
Manitoba & 0 & 0 & 0 & 95 \\
Tennessee & 0 & 0 & 13 & 80 \\
Wisconsin & 9 & 3 & 12 & 111 \\
Kentucky & 35 & 0 & 0 & 0 \\
Missouri & 19 & 1 & 0 & 0 \\
\hline
\end{tabular}

phenotypic hybrids and Blue-winged Warblers seen in the province. Less auspiciously, however, a male "Brewster's" Warbler hybrid was seen in the southeastern region of the province during the 2008 breeding season (C. Artuso, personal communication), which probably indicates that Blue-winged Warblers are continuing to expand their range (Gill et al. 2001).

It is also important to note that population estimates by Partners in Flight indicate that less than $1 \%$ of the global breeding population of Golden-winged Warblers can be found within the provincial borders of Manitoba each summer (Buehler et al. 2006), although data from recent surveys indicate that this estimate may be somewhat low (C. Artuso, personal communication). Despite these new data, and although Taylor (2003) provides some evidence that numbers of Golden-winged Warblers are increasing in Manitoba (22.66\%/yr increase, $N=2$ routes,
1988-2007, $p=0.42$ ), the density of birds in this province is still very low compared to populations in Minnesota, Wisconsin, and Ontario, which, combined, are home to $82 \%$ of the global population during the breeding season (Buehler et al. 2006, Sauer et al. 2008).

The finding that phenotypic Golden-winged Warblers in Minnesota show evidence of genetic introgression contradicts past work. Leichty and Grier (2006) relied on the assumption that they were studying a genetically pure population when making conclusions about female mate selection and the reproductive success of hybrids compared to "pure" Golden-winged Warblers, and the samples analyzed here came from the same population in which Leichty and Grier conducted their study. It is very disturbing to find mitochondrial introgression in Minnesota because $\sim 40 \%$ of the global population of Golden-winged Warblers breeds within that state. 
Fig. 1. A map of northeastern North America indicating the Golden-winged Warbler breeding range (shaded area). The dark sections of the pie charts in each state/province indicate the proportion of Golden-winged Warbler samples that were assigned to the ancestral Golden-winged Warbler haplotype group; the lighter grey areas represent the proportion of Golden-winged Warbler samples assigned to the Blue-winged Warbler haplotype group. Numbers within pie charts represent the number of Goldenwinged Warblers that were sampled per state/province. MB stands for Manitoba; ON, Ontario; QC, Quebec; MN, Minnesota; WI, Wisconsin; NY, New York; PA, Pennsylvania; WV, West Virginia; TN, Tennessee; and NC, North Carolina.

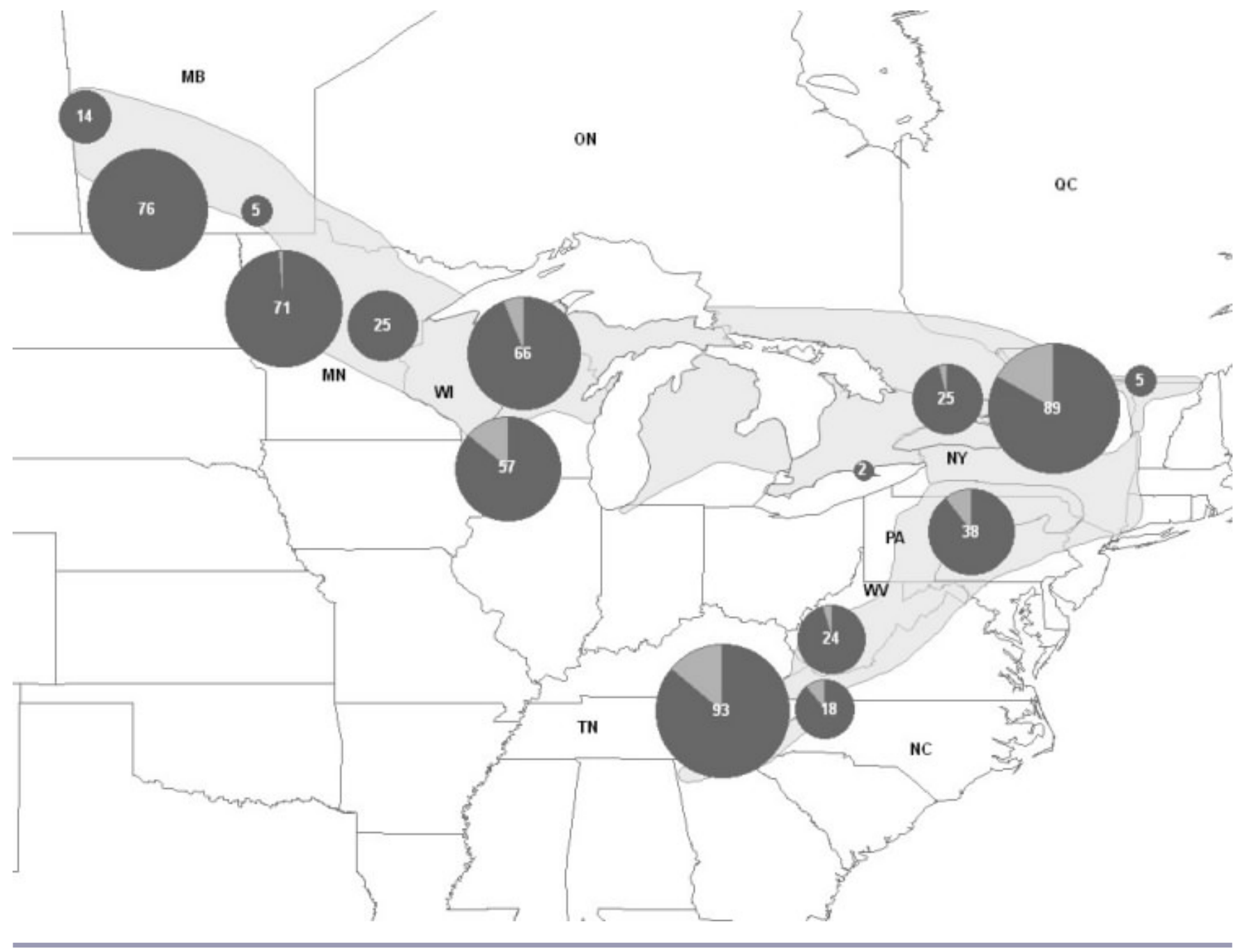

This is further exacerbated by population declines of -3.67\%/yr since 2003 in Minnesota (Sauer et al. 2008), a state in which the Golden-winged Warbler is not afforded any protection.

Although no introgression from Blue-winged to Golden-winged Warblers was found in southern
Ontario or Quebec, this is likely a consequence of low sample sizes rather than an absence of introgression. Moreover, the apparent lack of introgression from Golden-winged to Blue-winged Warblers in Quebec is also likely indicative of the small number of individuals we tested from this region. Hybrids are known to exist and breed in 
Fig. 2. A map of northeastern North America indicating the Blue-winged Warbler breeding range (shaded area). The dark sections of the pie charts in each state/province indicate the proportion of Bluewinged Warbler samples that were assigned to the ancestral Blue-winged Warbler haplotype group; the lighter grey areas represent the proportion of Blue-winged Warbler samples assigned to the Goldenwinged Warbler haplotype group. Numbers within pie charts represent the number of Blue-winged Warblers that were sampled per state/province. MB stands for Manitoba; ON, Ontario; QC, Quebec; WI, Wisconsin; NY, New York; MO, Missouri; KY, Kentucky; and WV, West Virginia.

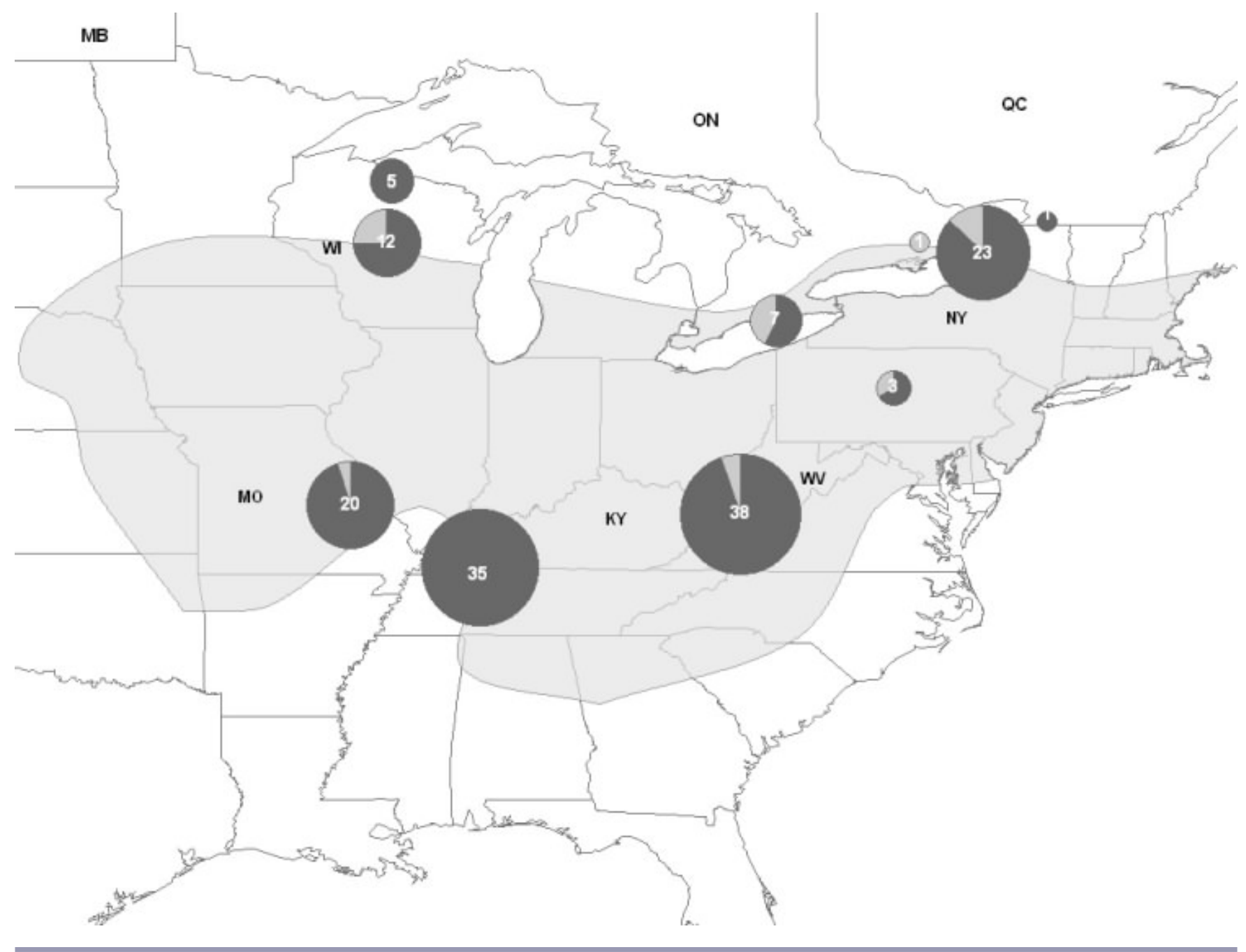

Ontario and Quebec, suggesting that interspecies gene flow and cryptic hybridization is ongoing (Vallender et al. 2007a,b). This finding supports earlier work that showed unidirectional introgression from Blue-winged to Golden-winged Warblers in a hybridizing population in Michigan (Gill 1997). However, analysis of samples collected in areas in which hybridization is known to be occurring in
West Virginia, Michigan, Pennsylvania, Wisconsin, Ohio, Ontario, and New York has shown that gene flow is bidirectional in most areas in which these species are in contact (Shapiro et al. 2004, Dabrowski et al. 2005). Moreover, individual-level parentage analysis within an active hybrid zone in Ontario has shown that hybrids are not at a reproductive disadvantage compared to phenotypic 
Golden-winged Warblers, thereby passing on their mtDNA to their offspring regardless of whether they have a Blue-winged or Golden-winged Warbler maternal ancestry (Vallender et al. 2007b).

If the pattern of rapid replacement of Goldenwinged Warblers by Blue-winged Warblers that has been observed in many other regions (Will 1986, Gill 1980, 1997) continues, we can assume that rates of introgression of Blue-winged Warbler genes into Golden-winged Warbler populations in Minnesota will increase in coming years (Gill et al. 2001). Furthermore, the genetically pure Manitoba population is separated from the introgressed Minnesota population by a relatively small geographic distance (approximately 270 miles/434 $\mathrm{km}$, see Fig. 1), suggesting that the Manitoba populations are threatened by the dispersal of introgressed individuals. The observation of a male "Brewster's" Warbler in extreme southeastern Manitoba in 2008 highlights this point. Thus, estimates of long-distance dispersal between populations may also be crucial to understanding the risk of introgression in populations that are currently genetically pure.

Rates of introgression in Minnesota will almost certainly increase, and it will be only a matter of time before Blue-winged Warbler genes will become prevalent in the Golden-winged Warblers breeding in the province of Manitoba. Once this has taken place, the last remaining pure population of Golden-winged Warblers will become genetically threatened, suggesting that threatened Goldenwinged Warblers in Canada may face genetic extinction in coming years. However, the existence of populations that remain largely, if not entirely, free from gene exchange highlights the importance of genetic work to identify, and subsequently protect, populations of Golden-winged Warblers.

Why Blue-winged Warblers rapidly replace Golden-winged Warblers in areas of sympatry remains unknown. Genetic surveys alone will not enable us to preserve populations of Golden-winged Warblers. Rather, their ultimate conservation will most likely come down to habitat manipulation, $i$. e., preserving habitat that is optimal for Goldenwinged Warblers and not for Blue-winged Warblers, thereby affording Golden-winged Warblers the chance to persist in an area without encroachment by Blue-winged Warblers. Habitat requirements for both species are similar; both require an early successional, scrubby area, because nests are placed on the ground, with a nearby forest edge containing trees that can be used for foraging and song posts (Confer 1992). Confer and Knapp (1981) suggest that Blue-winged Warblers tolerate slightly later stages of succession than do their Golden-winged counterparts, and recent work has suggested that Golden-winged Warblers may preferentially select areas with high herb cover and lower tree cover (Confer et al. 2003). However, more work is needed to determine the fine details of habitat selection by the two species.

As such, a collaborative effort by members of the Golden-winged Warbler Working Group (see http: //www.gwwa.org) is using the genetic data presented here, in combination with intensive onthe-ground surveys, habitat classifications, and experimental habitat manipulations and management, to try to determine which habitat variables, if any, differentiate the nesting habitats preferred by Golden-winged and Blue-winged Warblers. Effective on-the-ground landscape management and continued genetic surveys represent the last chance at survival for one of the most critically threatened wood-warbler species.

Responses to this article can be read online at:

http://www.ace-eco.org/vol4/iss2/art4/responses/

\section{Acknowledgments:}

This work was supported by the genetic component of a collaborative National Fish and Wildlife Foundation grant to $R V$ and IJL. Great thanks are given to the people who provided samples for this research, including Curtis Smalling (North Carolina), Dave Westneat (Minnesota samples collected by Ellen Leichty), Bob Rickleffs (Missouri), and Enid Cumming (Manitoba). Thanks also to the field assistants who aided in the collection of samples and to those who gave other support, including Wybo Vanderschuit (Manitoba), Riding Mountain National Park (Manitoba), Pauline Bloom (Manitoba), Keith Hobson (Manitoba), Nick Luff (Manitoba), Joe Grata (Pennsylvania), Kate Neville (Quebec), Sherilee Harper (Ontario), Marty Piorkowski (Ontario), Joseph Chernek (New York), PaulElsen (New York), Sara Barker Swarthout (New York), Elliott Swarthout (New York), Aaron Swartwood (New York), Laura Stenzler (New York), Ron Hull 
(northern Wisconsin), Chad Fitzmorris (northern Wisconsin), Tim Falconer (northern Wisconsin), Sarah Buman (northern Wisconsin), Vanessa Haese-Lehman (northern Wisconsin), Chris Waas (northern Wisconsin), Alex Wrobel (northern Wisconsin), Breanne Carne (northern Wisconsin), Jillian Schubert (northern Wisconsin), David Flaspohler (northern Wisconsin), Chris Webster (Wisconsin), Matt Timpf (Tennessee), B. Augustine (Tennessee), A.P. Raymundo (Tennessee), A. Pena (Tennessee), Scott Lutz (mid-Wisconsin), Karl Martin (mid-Wisconsin), Mike Cong (midWisconsin), Jean Mellen (mid-Wisconsin), Binga Elger (mid-Wisconsin), Carl Oppert (midWisconsin), Serena Grover (mid-Wisconsin), Srinivasan Kasturirangan (mid-Wisconsin), Bradley Gibbons (mid-Wisconsin), and the West Virginia field crew. Thanks to Laura Stenzler for conducting assays on the 2009 samples, and to Randy Dettmers for providing the breeding range maps. Financial support for the collection of field samples in Manitoba was provided in part by the Interdepartmental Recovery Fund Project (Project \#1362). The collection of samples in West Virginia was supported by the U.S. Fish and Wildlife Service and The Southern West Virginia Bird Research Center. Work in mid-Wisconsin was funded by the University of Wisconsin-Madison and the Wisconsin Department of Natural Resources through Pittman Robertson Project W-160-P. A great thanks is given to all the members of the Golden-winged Working Group with whom these authors are collaborating to preserve the Golden-winged Warbler throughout its breeding range.

\section{LITERATURE CITED}

Allendorf, F. W., R. F. Leary, P. Spruell, and J. K. Wenburg. 2001. The problems with hybrids: setting conservation guidelines. Trends in Ecology and Evolution 16:613-622.

Bronson, C. L., T. C. Grubb, G. D. Sattler, and M. J. Braun. 2003. Mate preference: a possible causal mechanism for a moving hybrid zone. Animal Behaviour 65:489:500.

Buehler, D. A., J. L. Confer, R. A. Canterbury, T. C. Will, W. C. Hunter, R. Dettmers, and D. Demarest. 2006. Status assessment and conservation plan for the Golden-winged Warbler, Vermivora chrysoptera, in the United States. Fish and Wildlife
Service Biological Technical Publication FWS/ BTP-R6XXX-2006. U.S. Department of the Interior, Washington, D.C., USA.

Buehler, D. A., A. M. Roth, R. Vallender, T. C. Will, J. L. Confer, R. A. Canterbury, S. Barker Swarthout, K. V. Rosenberg, and L. P. Bulluck. 2007. Status and conservation priorities of Goldenwinged Warblers (Vermivora chrysoptera) in North America. The Auk 124:1439-1445.

Butcher, G. S., D. K. Niven, A. O. Panjabi, D. N. Pashley, and K. V. Rosenberg. 2007. WatchList: the 2007 WatchList for United States birds. American Birds 61:18-25.

Confer, J. L. 1992. Golden-winged Warbler (Vermivora chrysoptera) In A. Poole, P. Stettenheim and F. Gill, editors. Birds of North America. Number 20. Academy of Natural Sciences, Philadelphia, Pennsylvania, USA, and American Ornithologists' Union, Washington, D. C., USA.

Confer, J. L., and K. Knapp. 1981. Goldenwinged Warblers and Blue-winged Warblers: the relative success of a habitat specialist and a generalist. The Auk 98:108-114.

Confer, J. L., J. L. Larkin, and P. E. Allen. 2003. Effects of vegetation, interspecific competition, and brood parasitism on Golden-winged Warbler (Vermivora chrysoptera) nesting success. The Auk 120:138-144.

Committee on the Status of Endangered Wildlife in Canada (COSEWIC). 2006. Canadian species at risk, May 2006. COSEWIC, Ottawa, Ontario, Canada.

Dabrowski, A. K., R. Fraser, J. L. Confer, and I. J. Lovette. 2005. Geographic variability in mitochondrial introgression among hybridizing populations of Golden-winged (Vermivora chrysoptera) and Blue-winged (V. pinus) Warblers. Conservation Genetics 6:843-853.

Gill, F. B. 1980. Historical aspects of hybridization between Blue-winged and Golden-winged Warblers. The Auk 97:1-18.

Gill, F. B. 1987. Allozymes and genetic similarity of Blue-winged and Golden-winged Warblers. The Auk 104:444-449. 
Gill, F. B. 1997. Local cytonuclear extinction of the Golden-winged Warbler. Evolution 51:519-525.

Gill, F. B. 2004. Blue-winged Warblers (Vermivora pinus) versus Golden-winged Warblers ( $V$. chrysoptera). The Auk 121:1014-1018.

Gill, F. B., R. A. Canterbury, and J. L. Confer. 2001. Blue-winged Warbler (Vermivora pinus). In A. Poole and F. Gill, editors. Birds of North America. Number 584. Academy of Natural Sciences, Philadelphia, Pennsylvania, USA, and American Ornithologists' Union, Washington, D. C., USA. Available online at: http://bna.cornell.edu/ BNA/.

Harrison, R. G. 1993. Hybrids and hybrid zones: historical perspectives. Pages $3-12$ in R. G. Harrison, editor. Hybrid zones and the evolutionary process. Oxford University Press, New York, New York, USA.

Hunter, W. C., D. A. Buehler, R. A. Canterbury, J. L. Confer, and P. B. Hamel. 2001. Conservation of disturbance-dependent birds in eastern North America. Wildlife Society Bulletin 29:440-455.

Leichty, E. R., and J. W. Grier. 2006. Importance of facial pattern to sexual selection in Goldenwinged Warbler (Vermivora chrysoptera). The Auk 123:962-966.

Mank, J. E., J. E. Carlson, and M. C. Brittingham. 2004. A century of hybridization: decreasing genetic distance between American black ducks and mallards. Conservation Genetics 5:395-403.

Parkes, K. C. 1951. The genetics of the Goldenwinged X Blue-winged Warbler complex. Wilson Bulletin 63:5-15.

Rhymer, J. M., and D. Simberloff. 1996. Extinction by hybridization and introgression. Annual Review of Ecology and Systematics 27:83-109.

Rich, T. D., C. J. Beardmore, H. Berlanga, P. J. Blancher, M. S. W. Bradstreet, G. S. Butcher, D. W. Demarest, E. H. Dunn, W. C. Hunter, E. E. Iñigo-Elias, J. A. Kennedy, A. M. Martell, A. O. Panjabi, D. N. Pashley, K. V. Rosenberg, C. M. Rustay, J.S. Wendt, and T. C. Will. 2004. Partners in Flight North American Landbird Conservation Plan. Cornell Laboratory of Ornithology, Ithaca, New York, USA.

Rohwer, S., E. Bermingham, and C. Wood. 2001. Plumage and mitochondrial DNA haplotype variation across a moving hybrid zone. Evolution 55:405-422.

Sattler, G. D., and M. J. Braun. 2000 . Morphometric variation as an indicator of genetic interactions between Black-capped and Carolina Chickadees at a contact zone in the Appalachian Mountains. The Auk 117:427-444.

Sauer, J. R., J. E. Hines, and J. Fallon. 2008. The North American breeding bird survey, results and analysis 1966-2007. U.S. Geological Service, Patuxent Wildlife Research Center, Laurel, Maryland, USA.

Schwartz, M. K., K. L. Pilgrim, K. S. McKelvey, E. L. Lindquist, J. J. Claar, S. Loch, and L. F. Ruggiero. 2004. Hybridization between Canada lynx and bobcats: genetic results and management implications. Conservation Genetics 5:349-355.

Shapiro, L. H., R. A. Canterbury, D. M. Stover, and R. C. Fleischer. 2004. Reciprocal introgression between Golden-winged Warblers (Vermivora chrysoptera) and Blue-winged Warblers (V. pinus) in eastern North America. The Auk 121:1019-1030.

Stapley, J., T. R. Birkhead, T. Burke, and J. Slate. 2008. A linkage map of the Zebra Finch Taeniopygia guttata provides new insights into avian genome evolution. Genetics 179:651-667.

Taylor, P. 2003. The birds of Manitoba. Manitoba Avian Research Committee, Altona, Manitoba, Canada.

Vallender, R., R. J. Robertson, V. L. Friesen, and I. J. Lovette. 2007a. Complex hybridization dynamics between Golden-winged and Bluewinged Warblers (Vermivora chrysoptera and $V$. pinus) revealed by AFLP, microsatellite, intron and mtDNA markers. Molecular Ecology 16: 2017-2029.

Vallender, R., V. L. Friesen and R. J. Robertson. 2007b. Paternity and performance of Goldenwinged Warblers (Vermivora chrysoptera) and 
Golden-winged X Glue-winged Warbler (V. pinus) hybrids at the leading edge of a hybrid zone. Behavioral Ecology and Sociobiology 61:1797-1807.

Will, T. C. 1986. The behavioral ecology of species replacement: Blue-winged and Golden-winged Warblers in Michigan. Dissertation. University of Michigan, Ann Arbor, Michigan, USA. 